\title{
Study of immunoglobulins in pleura and pleural effusions
}

\author{
L TELVI, ${ }^{1}$ F JAUBERT, ${ }^{2}$ A EYQUEM, ${ }^{3}$ J P ANDREUX, ${ }^{4}$ F LABROUSSE,,${ }^{4}$, \\ AND J CHRÉTIEN ${ }^{1}$
}

From the FRA $n^{0}$ 16, INSERM (Laboratoire de Pathologie Pleuro-Pulmonaire), Hôpital Laënnec, ${ }^{1}$

Laboratoire Central d'Anatomo-Pathologie, Hôpital Necker-Enfants Malades, ${ }^{2}$ Laboratoire

d'Immuno-Hématologie et d'Immuno-Pathologie, Institut Pasteur, ${ }^{3}$ and Laboratoire Central de

Biochemie, Hôpital Laënnec, ${ }^{4}$ Paris, France

\begin{abstract}
The protein concentration of 35 pleural effusions was compared with that in the serum. The ratio of the pleural and serum concentration of albumin, IgG, $\operatorname{IgA}$, and $\operatorname{IgM}$ is always below unity and appears to have no diagnostic value. However, the ratio of the concentration of these proteins was inversely related to their molecular weight. The underlying mechanism in malignant and inflammatory effusions appear similar and is in keeping with a diffusion process. Immunofluorescent staining of the pleura suggests the intercellular passage of the proteins through the mesothelial barrier.
\end{abstract}

There are very few reports of the distribution of plasma proteins in pleural effusions. The 52 cases studied by Zinneman et al (1957) showed a fair separation between transudate and exudate. All the plasma protein fractions contained in pleural effusion were in a distribution similar to that in the serum. In nine cases reported by Hirsch et al (1971) it was concluded that the immunoglobulin concentration in the pleural effusion was low compared with their amount in the serum. We compared the amount of serum protein in malignant and non-malignant pleural effusions with their level in the serum.

\section{Methods}

Pleural effusions were collected from 35 patients during one year. Total protein was measured by the biuret reaction. Albumin was measured by electrophoresis and the percentage calculated in relation to total protein. IgG, IgA, IgM, and IgD levels were measured by single radial immunodiffusion on plates (Behring). The results were expressed in $\mathrm{mg} / 100 \mathrm{ml}$. IgE concentration was determined by radioimmunoassay and expressed in $\mathrm{IU} / 100 \mathrm{ml}$.

Pleural biopsies were performed in 18 of the patients with an Abrams pleural punch biopsy needle. One piece from each was processed for immunofluorescence. The parietal pleural biopsy performed during a thoracotomy for lung biopsy was used as a control.

These fragments were immediately embedded in a cube of Cryoform TM (Damon Inc Division) and frozen instantaneously with liquid nitrogen. These cubes were stored at $-20^{\circ} \mathrm{C}$ until required. The embedded fragments were then cut in a Cryostat (Damon CTD Harris) at $-20^{\circ} \mathrm{C}$ into $4 \mu \mathrm{m}$ sections, laid on microscopic glass slides, and fixed for 10 minutes in absolute ethanol at $+20^{\circ} \mathrm{C}$. These sections were treated by a direct immunofluorescent method using monospecific serum labelled specifically for human IgG, IgA, IgM, IgE (Hyland), and IgD (Behring). The sera were tested before use by immunoelectrophoresis with standard normal human serum (Behring). The sections were incubated with the conjugates diluted to $1 / 5,1 / 10$, and $1 / 20$ for 30 minutes at $20^{\circ} \mathrm{C}$, rinsed with two baths of Coons buffer, pH 7.4, for 15 minutes each, and were mounted in glycerol at $50 \%$.

A Leitz fluorscence microscope was used for observation.

\section{Results}

PLEURAL EFFUSION PROTEINS

The 35 effusions were exudates, having a pleural fluid protein concentration greater than $3 \mathrm{~g} /$ $100 \mathrm{ml}$. They were divided into three groups according to the causal lesion: 14 were of carcinomatous origin, 10 tuberculous, and $11 \mathrm{miscel}-$ 
laneous inflammatory conditions.

The levels of proteins in the pleural effusions were divided by the amount of protein in the corresponding serum to give the ratio $\mathrm{C}$.

The different proteins were put in order according to their molecular weight. The filtration coefficient $\mathrm{C}$ used was always below unity. The mean level $(\overline{\mathrm{m}})$ of $C$ was inversely related to the molecular weight of the proteins involved (fig 1). Analysis of the results showed that the statistical differences between albumin $(\overline{\mathrm{m}}=0.68)$ and IgM $(\bar{m}=0.50)$ and between IgG $(\bar{m}=0.65)$ and IgM $(\overline{\mathrm{m}}=0.50)$ were significant $(\mathrm{P}<0.02)$.

In contrast the comparison of the different $\mathrm{C}$ ratios according to the aetiological group of the pleural effusion did not give significant results (fig 2).

\section{IMMUNOFLUORESCENCE STAINING ON PLEURAL}

BIOPSIES

In all pathological cases the continuous barrier of mesothelial cells had disappeared except in some focal areas, and inflammatory cells were observed. Interstitial and vascular fluorescence for IgG, IgA, and IgM was seen. The results were estimated from ( +$)$ to $(+++)$ according to the fluorescent intensity observed at the same dilution level $(1 / 10)$, and the results obtained matched the biochemical measurements (see table). Plasmacytes were observed in some cases (fig 3). No fluorescence was seen for IgE and IgD and no nuclear fluorescence was observed in any case. These results show that immunoglobulins are probably absorbed in the pleural interstitium.

In the parietal pleural biopsy performed during a thoracotomy the barrier of mesothelial cells was present and their surfaces and the intercellular

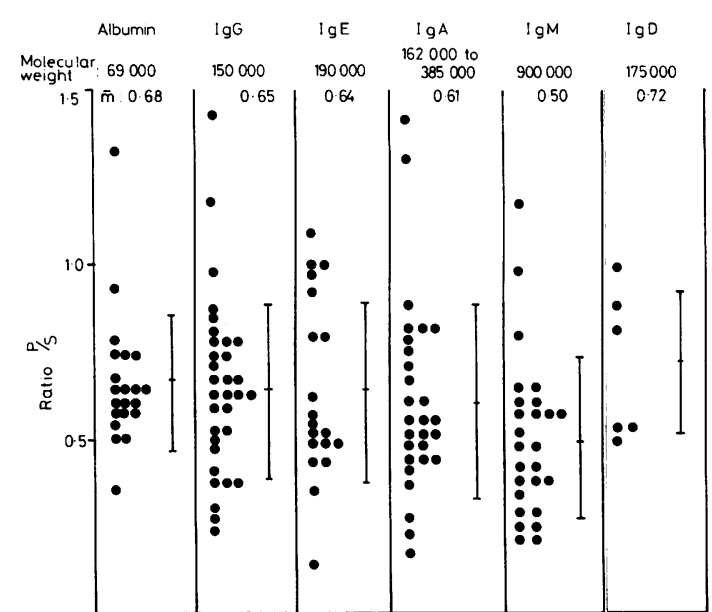

Fig 1 Different proteins according to their molecular weight. Filtration coefficient:

(Ratio $P / S) C=\frac{\text { Pleural protein }}{\text { Serum protein }}$

is expressed for each case. Mean $(\bar{m})$ level increases when protein molecular weight decreases.

spaces were outlined, but no intracellular fluorescence was observed (fig 4).

\section{Discussion}

The results obtained by the measurement of serum and pleural effusion proteins lead to the following conclusions.

In accordance with the work of Chrétien (1970, 1972) the level of the different protein classes studied did not have a diagnostic value for

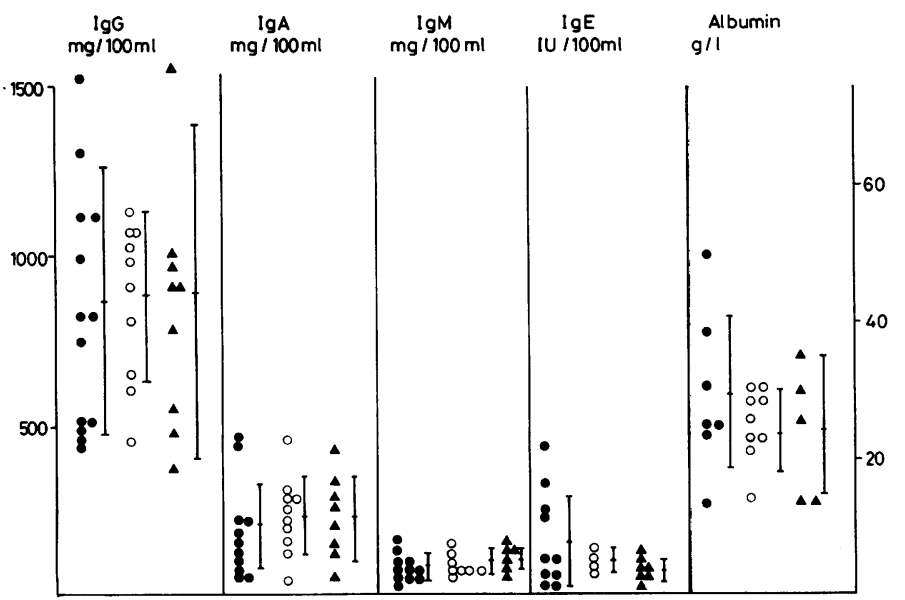

Fig 2 Concentration of different proteins in relation to aetiology: carcinomatous disease $(\Theta)$, tuberculous disease $(O)$, miscellaneous disease $(\Delta)$. There was no significant difference between the three groups. 
Immunofluorescent staining on pleural biopsy (IFS on PlB) graded from $(+)$ to $(+++)$ according to fluorescent intensity observed at same dilution level $(1 / 10)$, related to aetiology and to serum protein level for $\mathrm{IgG}$. Serum and pleural effusion levels of proteins are expressed in $\mathrm{mg} / 100 \mathrm{ml}$

\begin{tabular}{|c|c|c|c|c|c|c|c|c|c|c|}
\hline \multirow{2}{*}{$\begin{array}{l}\text { Case } \\
\text { no }\end{array}$} & \multirow[t]{2}{*}{ Aetiologies } & \multicolumn{3}{|l|}{$I g G$} & \multicolumn{3}{|l|}{$\operatorname{Ig} A$} & \multicolumn{3}{|l|}{$I g M$} \\
\hline & & $\begin{array}{l}\text { Serum } \\
\text { level }\end{array}$ & $\begin{array}{l}I F S \text { on } \\
P I B\end{array}$ & $\begin{array}{l}\text { Pl Eff } \\
\text { level }\end{array}$ & $\begin{array}{l}\text { Serum } \\
\text { level }\end{array}$ & $\begin{array}{l}\text { IFS on } \\
\text { PIB }\end{array}$ & $\begin{array}{l}\text { Pl Eff } \\
\text { level }\end{array}$ & $\begin{array}{l}\text { Serum } \\
\text { level }\end{array}$ & $\begin{array}{l}\text { IFS on } \\
P I B\end{array}$ & $\begin{array}{l}\text { Pl Eff } \\
\text { level }\end{array}$ \\
\hline $\begin{array}{r}27 \\
57 \\
15 \\
6 \\
23\end{array}$ & Tuberculous disease & $\begin{array}{r}1930 \\
1590 \\
1490 \\
1290 \\
800\end{array}$ & $\begin{array}{l}+++ \\
+++ \\
++ \\
+++ \\
+++\end{array}$ & $\begin{array}{r}460 \\
1020 \\
900 \\
970 \\
1150\end{array}$ & $\begin{array}{l}168 \\
129 \\
142 \\
110 \\
230\end{array}$ & $\begin{array}{l}+ \\
+ \\
+ \\
+ \\
+\end{array}$ & $\begin{array}{r}62 \\
62 \\
140 \\
62 \\
62\end{array}$ & $\begin{array}{l}246 \\
412 \\
200 \\
257 \\
236\end{array}$ & $\begin{array}{l}+++ \\
++ \\
++ \\
++ \\
+++\end{array}$ & $\begin{array}{r}46 \\
280 \\
284 \\
208 \\
110\end{array}$ \\
\hline $\begin{array}{l}16 \\
1 \mathrm{~b} \\
25 \\
52 \\
22 \\
24\end{array}$ & Carcinomatous disease & $\begin{array}{r}2000 \\
1990 \\
1670 \\
1420 \\
1340 \\
590\end{array}$ & $\begin{array}{l}+++ \\
+++ \\
+++ \\
+++ \\
+++ \\
+++\end{array}$ & $\begin{array}{r}1000 \\
830 \\
470 \\
1170 \\
46 \\
510\end{array}$ & $\begin{array}{r}76 \\
138 \\
248 \\
187 \\
258 \\
62\end{array}$ & $\begin{array}{l}0 \\
+ \\
+ \\
+ \\
+ \\
0\end{array}$ & $\begin{array}{l}20 \\
35 \\
64 \\
90 \\
62 \\
62\end{array}$ & $\begin{array}{l}510 \\
784 \\
312 \\
400 \\
284 \\
262\end{array}$ & $\begin{array}{l}++ \\
+++ \\
+++ \\
+++ \\
++ \\
+++\end{array}$ & $\begin{array}{r}440 \\
212 \\
164 \\
222 \\
71 \\
150\end{array}$ \\
\hline $\begin{array}{l}18 \\
33 \\
30 \\
29 \\
14\end{array}$ & $\begin{array}{l}\text { Miscellaneous Inflammatory } \\
\text { disease }\end{array}$ & $\begin{array}{l}2280 \\
1450 \\
1450 \\
1240 \\
1140\end{array}$ & $\begin{array}{l}+++ \\
+++ \\
+++ \\
+++ \\
++\end{array}$ & $\begin{array}{c}2050 \\
1000 \\
900 \\
370 \\
\text { ND }\end{array}$ & $\begin{array}{r}219 \\
110 \\
95 \\
166 \\
62\end{array}$ & $\begin{array}{l}+ \\
+ \\
+ \\
++ \\
+\end{array}$ & $\begin{array}{r}123 \\
62 \\
113 \\
62 \\
49\end{array}$ & $\begin{array}{l}490 \\
168 \\
N D \\
420 \\
188\end{array}$ & $\begin{array}{l}+++ \\
++ \\
+++ \\
+++ \\
++\end{array}$ & $\begin{array}{l}278 \\
135 \\
254 \\
\text { ND } \\
245\end{array}$ \\
\hline
\end{tabular}

$\mathrm{ND}=$ Not done.

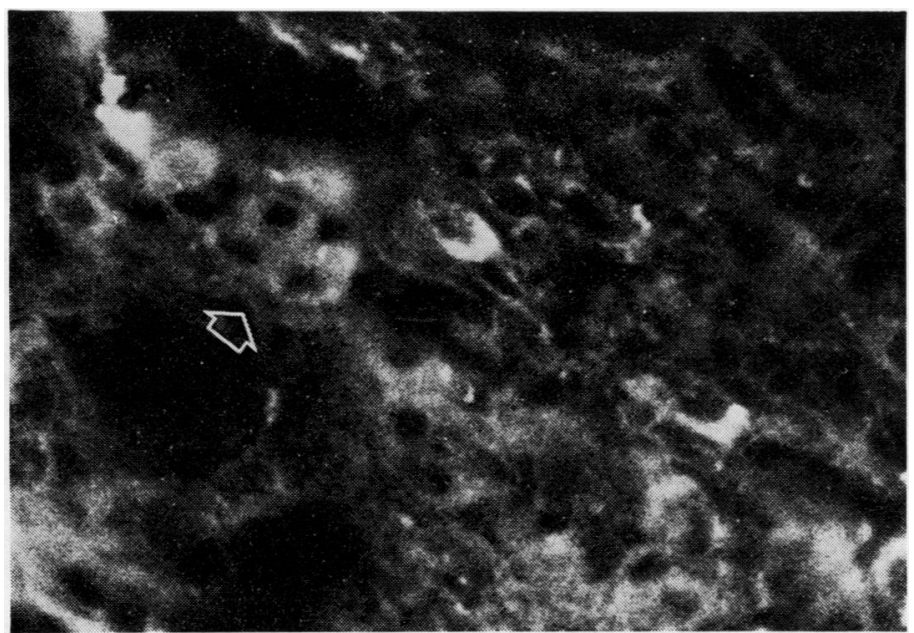

Fig 3 Immunofluorescence staining for IgG of pleura from a patient with effusion. Continuous barrier of mesothelial cells has disappeared and some plasma cells are present (arrow). Interstitial fluorescence was observed (X40).

the compleural exudates (fig 2). The comparison of the amount of IgG between the carcinomatous and the tuberculous groups showed no statistical difference. We did not observe in our patients the differences reported by Kay et al (1976), though these authors expressed their results is IU of immunoglobulin per mg protein and are thus not strictly comparable with ours.

The level of serum protein in the pleural effusion was always below that in the corresponding serum. Our findings are in accordance with those reported by Zinneman et al (1957), Hirsch et al (1971), and Agostini and Marasini (1977). The C ratio as related to the molecular weight of the protein and the differences for albumin, IgG, and IgM were statistically significant $(P<0.02)$. The rate of diffusion is different according to the molecular or physical properties of that substance. Sodium and para-aminohippuric acid have a rapid elimination and are reabsorbed by the capillaries of visceral pleura (Agostoni, 1969; Stewart, 1963). Proteins from pleural effusions are removed by the lymphatics as found in dogs by Stewart and Burgen (1958), and in cats by Courtice and Simmonds (1949). In patients with pleural effusion a breakdown of the equilibrium between the entry and the output of fluid and proteins from the pleural space has been well documented by Stewart (1963), using para-aminohippuric acid and protein labelled T 1824. An exclusive lymphatic reabsorption process was suggested for albumin. However, the immunoglobulin removal mechanism from the pleural space was not specified.

Our results show that the immunoglobulins 


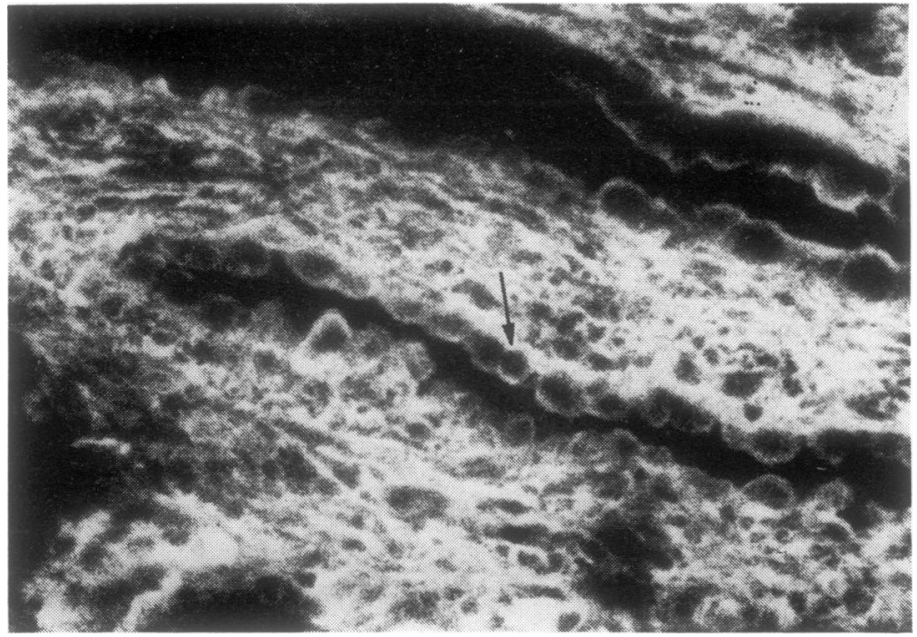

Fig 4 Immunofluorescent staining for IgG of a biopsy of normal pleura. Mesothelial cell barrier is continuous and reaction outlines cell surfaces (arrow), intercellular spaces, and interstitium. There was no cytoplasmic or nuclear fluorescence. Some plasma cells are present $(\times 25)$.

diffuse in the same way as the other serum proteins, in inverse relation to their molecular weight.

The similarity of the fluid composition, whatever the pathological process, shows a similar mechanism of constitution for the different kinds of pleural effusion. It may be related to the release of inflammatory mediators in response to vascular obstruction (Meyer, 1966) or to an immunological reaction of the host against a tumour or an infection. These facts agree with the results of Agostini and Marasini (1977).

The results obtained by immunofluorescent staining show the interstitial location of the plasma proteins and their intercellular passage through the mesothelial barrier. There was no demonstration of active intracellular transport.

The involvement of the mesothelial cell barrier in the protein exchange of pleural fluid is not well defined; it may be related to an active opening of the intercellular spaces by contraction as reported for the endothelial cells (Ryan and Maino, 1977) or to the destruction of the mesothelial barrier as in the present study. The action of the pleural interstitium in the serum and pleural exchanges for fluids and proteins remains ill-defined.

\section{References}

Agostini, A, and Marasini, B (1977). Orosomucoid contents of pleural and peritoneal effusions of various etiologies. American Journal of Clinical Pathology, 67, 146-148.

Agostoni, E (1969). Thickness and pressure of the pleural liquid. In The Pulmonary Circulation and Interstitial Space, edited by A P Fishman and H H Hecht, pp 65-77. University of Chicago Press,
Chicago.

Chrétien, J (1970). Quelques aspects immunologiques $\vec{\bullet}$ des maladies de la plèvre. Presse Medicale, 78, ฮै 921-925.

Chrétien, J (1972). Etiologie et problèmes de diagnostic. In Les Épanchements non Purulents de al Plèvre, edited by J Chrétien, pp 1-7. L'Expansion Scientifique Française, Paris.

Courtice, F C, and Simmonds, W J (1949). Absorption of fluids from the pleural cavities of rabbits and cats. Journal of Physiology, 109, 117-130.

Hirsch, A, Papiernik, M, Saint-Paul, M, Bonnaud, G, and Chrétien, J (1971). Exploration de certaines réactions immunitaires au cours des épanchements pleuraux. Presse Medicale, 79, 2421-2426.

Kay, A B, Smith, A F, McGavin, C R, and Tuft, S B (1976). Immunoglobulins and complement in ® pleural effusions associated with bronchogenic car- $\dot{0}$ cinoma. Journal of Clinical Pathology, 29, 887889.

Meyer, P C (1966). Metastatic carcinoma of the pleura. Thorax, 21, 437-443.

Ryan, G B, and Maino, G (1977). Acute inflammation. ㅇ American Journal of Pathology, 86, 185-274.

Stewart, P B (1963). The rate of formation and lymphatic removal of fluid in pleural effusions. N Journal of Clinical Investigation, 42, 258-262.

Stewart, P B, and Burgen, A S V (1958). The turn- N over of fluid in the dog's pleural cavity. Journal of N Laboratory and Clinical Medicine, 52, 212-230.

Zinneman, H H, Johnson, J J, and Lyon, R H (1957). Proteins and mucoproteins in pleural effusions. American Review of Tuberculosis and Pulmonary $\mathbb{D}$ Diseases, 76, 247-255.

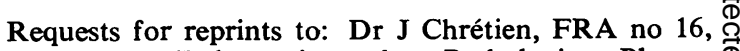
INSERM (Laboratoire de Pathologie Pleuro- $\mathbb{D}$ Pulmonaire), Hôpital Laënnec, 42 rue de Sèvres, $\frac{0}{0}$ 75007-Paris. 